NBER WORKING PAPER SERIES

CREDIBLE COMMITMENT AND

EXCHANGE RATE STABILITY:

CANADA'S INTERWAR EXPERIENCE

Michael D. Bordo

Angela Redish

Working Paper No. 2431

NATIONAL BUREAU OF ECONOMIC RESEARCH

1050 Massachusetts Avenue

Cambridge, MA 02138

November 1987

The authors are Visiting Professor, GSIA, Carnegie Mellon University, and Assistant Professor, Department of Economics, University of British Columbia, respectively. They wish to thank Shirley Haun for research assistance, the Bank of Nova Scotia Archives for access to their material, and, especially, Ronald A. Shearer for donating his data to us, and for his comments. Helpful comments on an earlier draft were supplied by Barry Eichengreen, Peter Howitt, David Laidler, Anna Schwartz, and Peter Temin. The usual disclaimer applies. The research reported here is part of the NBER's research program in Financial Markets and Monetary Economics. Any opinions expressed are those of the authors and not those of the National Bureau of Economic Research. 


\section{Credible Commitment and Exchange Rate Stability: \\ Canada's Interwar Experience}

\section{ABSTRACT}

In January 1929 the Canadian government suspended gold exports and began a floating exchange rate regime that endured until the onset of World War II. In sharp contrast with the experience of other countries which left the gold standard, deflation and declining economic activity continued in Canada until 1933.

This paper examines the determinants of the Canadian exchange rate in the 1930's and provides an answer to the question of why the Canadian dollar did not depreciate in the early 1930's despite Canada's de facto departure from the Gold Standard. We develop the answer in two stages. First, we show that the government made a clear commitment to maintain a contractionary monetary policy. It did so because it believed: that monetary expansion would increase the value of external obligations without reducing the value of domestic obligations; and that even if all contractual obligations were met, Canada would lose her reputation as a responsible debtor. Second, we argue that the government's commitment was viewed by the public as credible. The credible commitment dominated market agent's expectations of the evolution of the exchange rate.

Michael D. Bordo Graduate School of Industrial Administration Carnegie Mellon University Pittsburgh, PA 15213
Angela Redish Department of Economics University of British Columbia Vancouver, B.C. V6T 1Y2 
I. Introduction

It has long been believed that many countries successfully extricated themselves from the ravages of the Great Depression by cutting the fixed exchange rate link of the gold standard, hence freeing themselves to pursue expansionary monetary and fiscal policies and allowing their exchange rates to depreciate. In January 1929 the Canadian government suspended gold exports and began a floating exchange rate regime that endured until the onset of World War II. In sharp contrast with the experience of other countries which left the gold standard, deflation and declining economic activity continued in Canada until 1933, in concert with the experience of the United States (see Figures 1 and 2). The Canadian dollar did not depreciate until late 1931 (see Figures 3 and 4) and, (as Figure 5 shows) the nominal money stock declined.2

The behaviour of the exchange rate is shown in Figures 3 and 4 (Figure 4 shows the price of gold in each country). From January 1929 to September 1931 the Canadian dollar remained at or close to par with respect to both the U.S. dollar and the British pound. Between October 1931 and March 1933 the Canadian dollar depreciated (vis a vis the U.S. dollar) about half as much as the pound. Finally, after approximately a year of transition, all three currencies reestablished their traditional parities (albeit at a much higher gold price).

This paper examines the determinants of the Canadian exchange rate in the 1930s including the question of why the Canadian dollar did not depreciate in the

1 Irving Fisher (1935) first made the argument. For the case of Sweden, see Jonung (1981), for Norway, Denmark and Finland, see Choudhri and Kochin (1980), for Australia see Schedvin (1970) and Eichengreen (1985), for the United Kingdom see Beenstock et al (1984). For the beneficial economic effects of devaluations in the 1930s see Eichengreen and Sachs (1986).

2 In Canada the decline in $M 1$ occurred through a decrease in the stock of high powered money, rather than through a fall in the money multiplier as in the United States. 
early 1930s despite Canada's de facto departure from the gold standard. We develop the answer in two stages: first, we show that the government made a clear commitment to maintain a contractionary monetary policy; and second, we argue that the commitment was viewed by the public as credible. The credible commitment dominated market agent's expectations of the evolution of the exchange rate during the early 1930 s.

In the next section we describe the institutional framework and in the third we present the government's reasons for desiring exchange rate stability. We then attempt to quantify the costs and benefits of depreciation, and conclude that based on the assumptions and objectives of the government of the day, depreciation and monetary expansion would have been irrational. Understanding of this fact by the public made the government's commitment to sound monetary policy credible. Consequently, in the final section we argue that before September 1931 the public's expectations were of exchange rate stability. Following Britain's abandonment of the gold standard in October 1931, the public assigned a non-zero probability $\lambda$ to maintaining the traditional parity with sterling, (that is, a depreciation against the U.S. dollar) and a probability $(1-\lambda)$ to maintaining parity with the U.S. dollar. Econometric analysis shows that the data are consistent with this hypothesis.

\section{The Institutional Framework.}

We begin by describing the monetary institutions of the 1926-28 period and then describe the operation of the monetary system after the suspension of the gold standard.

Canada suspended the gold standard in 1914, in reaction to the onset of World War 1, and returned to convertibility twelve years later in July 1926. The 
legal tender money stock then consisted of gold coin and government issued Dominion Notes convertible into gold on demand at the rate $\$ 20.67$ per ounce of gold. The Department of Finance issued Dominion Notes, under two different pieces of legislation. "The Dominion Notes Act permitted a fiduciary issue of $\$ 63.5$ million with a $25 \%$ gold reserve, with any excess being $100 \%$ gold-backed. Under the Finance Act, Dominion Notes could also be issued if a chartered bank applied for a loan and supplied acceptable (broadly defined) collateral. These notes were not included in the total subject to the Dominion Notes Act. The banks applied for a line of credit each year from the Department of Finance and could borrow reserves up to that limit at the current discount rate. This was the discount window.

In late 1928 the inconsistency between the Finance Act and the gold standard became obvious. Call rates in New York rose to $8 \%$, far higher than the 5\% discount rate at the Department of Finance. The Canadian banks profited by borrowing Dominion Notes from the Department and converting them into gold for export and investment in New York. In the face of this drain on their reserves, the Canadian government instructed the Canadian banks to halt the export of gold. Thereafter, Dominion Notes were, in effect, inconvertible, and gold for export could be obtained only by arrangement with the Department of Finance. ${ }^{4}$ As Knox (1939; 20) reports, "the price of foreign exchange was free to vary according to conditions in a free market". The unofficial embargo on exports continued until October 19, 1931 when an Order-in-Council officially suspended gold exports. Throughout the 1930s internal convertibility was maintained, that is, the Canadian banks were required to maintain the convertibility of their notes and demand

3 Canada did not establish a central bank until 1935. For an analysis of the factors leading to the establishment of the Bank of Canada, see Bordo and Redish (1987).

4 This period is analyzed in detail in Shearer and Clark (1984). 
deposits into Dominion Notes.

After the prohibition on gold exports, the stock of high powered money was primarily determined by the government. Changes in the stock of high powered money could occur through changes in the quantity of Dominion Notes in circulation which in turn required either an amendment to the Dominion Notes Act or an increase in the advances to the chartered banks under the Finance Act. Since, in this paper, we focus on the behaviour of the government we briefly address here the banks' ability to affect the stock of high powered money.

The commercial banking system was a small group (ten) of private chartered banks, each with many branches. The system was highly concentrated with the three largest banks (the Bank of Montreal, the Bank of Commerce and the Royal Bank) holding $75 \%$ of the assets. The banks issued circulating notes, demand deposits and time deposits. The banks were quite closely regulated. Although there was no reserve requirement, $40 \%$ of reserves held were required to be Dominion Notes. Interest rates of higher than $7 \%$ were prohibited, as was lending secured by real estate. In 1890 the banks formed the Canadian Bankers' Association which operated a clearing house in Montreal, and generally operated as a lobby group/producer's association. In 1901 the Bank Act amendment recognized the Canadian Bankers' Association as "an agency for the supervision and control of certain activities of the banks" (Watts, 1972; 18).

The banks could increase the stock of high powered money by increasing their borrowing from the government. Since no bank came close to using up its line of credit with the Department of Finance during this period, it is possible to

5 Neither of these seems to have been completely enforced; interest rates greater than $7 \%$ were not illegal, but collection of rates greater than $7 \%$ could not be enforced through the courts. Nixon (1937; 432) states that between 1900 and 1930 farmers in Eastern Canada paid on average $7-8 \%$ interest on loans, and in Western Canada 6-10\%. 
argue that the base was demand determined, and that it was the banks' failure to borrow the available reserves that explains the monetary contraction (Clark and Shearer, 1976, 29).

The autonomy of the banks was, however, limited by the government's control over the discount rate. This rate was rarely changed and was not used as an instrument of short-run policy, but a letter sent by the Minister of Finance to the President of the Canadian Bankers' Association in August 1929 enclosed a copy of a memo (prepared by the Department for the House of Commons) stating the Department's willingness to control the banks by changing the discount rate:

If the Treasury should at any time feel convinced that Dominion Notes issued to banks against securities are being used other than for the purpose for which they are issued, the rate of interest charged the banks for such issues will be raised to a rate which will prohibit such misuse. (Archives of the Bank of Nova Scotia \#69-52, Sec. 1, File 84 "Gold" Memorandum on Exchange and Gold Reserves and Operations of the Finance Act, 1914.)

Both the government and the banks knew that the price of loans to the banks was in the hands of the government which would feel free to vary the price to achieve its policy goals. If the banks had attempted a monetary expansion, based on borrowing reserves from the government at a fixed nominal interest rate, the government would have increased the rate. ${ }^{6}$

- The monopoly structure of the banking system suggests that they might have an incentive to expand the money stock, and that the profit maximizing rate of expansion might have been quite high. However, to the extent that the banks believed the government's commitment (described below) to resume the gold standard at the old parity, the potential benefits from monetary expansion were very limited. If the banks undertook a monetary expansion yielding a potential depreciation of bank notes against gold, agents would have an incentive to hoard the notes pending resumption. The banks would then have to increase their reserves prior to resumption absorbing much of the potential seignorage revenue. 
III. The Government's Stated Policy.

Between January 1929 and September 1931 the Canadian government made clear its commitment not to depreciate the exchange rate or increase the money stock. The primary tools of monetary policy available to the government were the interest rate on Finance Act advances, and amendments to the Dominion Notes Act. The latter would have been the most straightforward, and either an increase in the quantity of notes requiring only $25 \%$ gold backing or a lowering of the $25 \%$ ratio, would have increased the stock of high powered money.

An alternative expansionary policy would have been to lower the discount rate on Finance Act advances. From late 1929 until late 1933 the advance rate lay above the New York commercial paper rate. (There is no equivalent Canadian commercial paper rate and we assume that short-term Canadian interest rates were similar to those in the New York market). A decline in the advance rate would have led to an increase in advances and a monetary expansion. For example, in the early 20 s the government lowered the advance rate below the New York commercial paper rate, and the money stock expanded (Clark and Shearer, 1976).

Though the government had the tools to conduct an expansionary policy it did not do so. The government's position which it stated frequently and publicly, and which we document below, was that it would not undertake any policy that would lead to a depreciation of the Canadian dollar. This government policy was endorsed by the major Opposition party.

Between July 1930 and 1935 the Conservative government of Prime Minister R.B. Bennett was in power. During this period backbenchers frequently proposed motions to increase the unbacked portion of the domestic money stock and the 
government repeatedly voted against such motions. In September 1930, during a special session of Parliament held to address the problem of unemployment. the government was asked to undertake a public works program to be funded by printing unbacked Dominion Notes. Prime Minister Bennett responded as follows:

Unless the paper money of this country has behind it an adequate reserve of the only commodity that passes in the settlement of international exchanges namely, goid, I would suggest that it is of very little value; and to the extent to which the reserve may be depleted or the ratio decreased by the issue of legal tender or of Dominion of Canada bills, to that extent is there a possibility of the money of this country becoming debased and not of par value in the countries of the world. (Canada, House of Commons, [henceforth HC], 1st S, 17th P, p.78)

The response was similar eighteen months later when the Prime Minister again argued that monetary expansion would not reduce unemployment but would ruin Canada's reputation as a sound debtor:

If 1 thought for a single moment that to add, beyond $\$ 71$ million of the present outstanding unsecured paper money of this country, another 25 or 30 or 40 millions of dollars would cure unemployment, would lift the Depression and would end all our troubles, I would have no more hesitancy in asking the House for it than I have in asking the House to pass any estimate that is submitted to it ... ... Moreover if its credit abroad is to be considered, if our reputation for meeting our obligations is to be considered, does anyone for a moment suggest that we could substitute the notes of the Dominion of Canada to pay bills in New York? (HC, 3rd S, 17th P, p. 650)

Since the House was not in Session in September 1931 there was little debate about the ban placed on gold exports in October 1931, however, in the Budget speech on April 6, 1932, the Minister of Finance argued: "It was imperative that there be no flight from the Canadian dollar through fear of infiation" (HC 3rd S, 17th P, P. 1749). Again an amendment to suspend the gold backing of the Dominion Notes was defeated as Liberals and Tories voted against it. The Prime Minister argued that depreciation "would be ruinous alike to the credit and to the future development of this country" $(H C, 3 r d S, 17$ th $P, P$. 2402). 
Later, in October 1932, the Minister of Finance described the government's

monetary stance:

There has been no matter of greater concern to this administration than the responsibility for the maintenance of the integrity of our financial structure and the credit of the Dominion as a whole ... [We have undertaken] the most tireless efforts ... to see that that precious thing called public credit, upon which the integrity of this country has depended for half a century shall be maintained and that no cheap nostrums in the form of quack remedies supplied by printing presses should take the place of a proper discharge of our contractual obligations. (HC, 4th S, 17th P, P. 53).

Six months later, in the budget speech he argued,

During the past year Canada was the only country that was able to borrow in the public markets of the U.S. This enviable position has been and can be held only by the maintenance of sound financial and monetary policies ... Let the sponsors of inflation never forget that apart from the other difficulties and dangers involved in their program one inevitable result would be a flight from our dollar, a withdrawal on a large scale of the capital invested by foreigners in this country in the form of securities and bank deposits. (HC, 4th S, 17th P, P. 3208)

The assumption underlying this statement is, of course, that some inflation/depreciation will lead speculators to expect more, and that capital flows were highly sensitive to even the slightest anticipation of depreciation.

The Liberal party held very similar views on monetary policy to those of their Conservative colleagues. The session of early 1930 had ended with a Liberal member (Mercier) applauding his government, for maintaining the redeemability of Canadian paper money "the strongest proof of Canada's exellent standing in the eyes of its citizens and of the whole world" (HC, 4th S, 16th P, P. 2112).

In opposition the party continued to endorse 'hard money' policies with the same rationale as the Conservatives: monetary expansion would cause a depreciation of the exchange rate and a loss of confidence in the Canadian dollar, but would not increase employment. In 1931, during discussion of a backbencher's motion to use monetary expansion to increase employment, the Leader of the Liberal party (W. L. McKenzie King) argued: 
Did I believe that this would make matters any better, I am not afraid to say that I should be among those who would support it ... This is a matter which is giving rise to a great deal of study on the part of the most thoughtful economists and the most earnest of social reformers and workers, and there is at the present time no general consensus of view which one can say is accepted. (HC, 2nd S, 17th P, p. 2669)

He had three other arguments against suspension of redeemability;

1. the purchasers of the conversion loan would be treated unfairly, i.e. they had a right to expect their bonds to be paid in notes redeemable in gold;?

2. that it would "declare to the world that we have lost confidence in our own financial and industrial position" ( $H C$, 2nd S, 17th P, P. 2770);

3. that since traded goods prices are exogenous Canada would not earn any more foreign exchange by depreciating.

In summary, the government and the major opposition party opposed depreciation on the grounds that it would not generate significant economic benefits, and because of concern over maintaining Canada's reputation in world capital markets.

The government's position was clearly stated and well known, but its credibility in the eyes of the public depended on two additional factors: the perceived rationality of the policy, and the consistency between the government's monetary and fiscal policy. Table $I$ shows that until $1930 / 31$ the federal government budget was in surplus and that subsequently the government ran a deficit. However, the increases in government expenditure and decrease in tax revenues were induced by the fall in economic activity and the government responded by slashing discretionary expenditures and increasing tax rates. ${ }^{8}$ While

7 The conversion loan is described in detail below. It transformed a little over a quarter of the outstanding government debt from gold denomination to Canadian currency denomination.

3 The increase in Special Expenditures after 1930 is almost entirely accounted for by increasing expenditures on Unemployment Relief. Ordinary Expenditures declined after March 1931 due to a decline in expenditures in most Departments, especially 
the calculations have not been done for Canada, it seems likely that, as in the United States (Brown, 1956), on a full employment basis the Canadian government was running a budget surplus, throughout the Depression years. Thus statements that the money supply would not be increased were not rendered in-credible by a fiscal policy that implied a need for money creation to finance a full employment budget deficit.

\section{The Rationality of the Government's Policy.}

We view the government as having conducted a cost-benefit analysis of the decision to depreciate. The benefits of depreciation for real economic activity and the government's real wealth were weighed against the costs to the government of losing its reputation as a sound debtor.' The government's decision not to depreciate reflected, we argue, their conclusion that the potential benefits were outweighed by the cost of a lost reputation. The public in turn perceived the rationality of the government's decision, making its policy credible.

\section{(i) Depreciation and Economic Performance}

As Eichengreen and Sachs (1986) have pointed out, there is a clear ex post correlation between exchange rate depreciation and improved economic performance. Their reduced form analysis can be used to suggest a possible measure of the output costs of a refusal by the government of Canada to depreciate. They measure the effect of depreciation by comparing the extent of depreciation with the decline in industrial production in ten European countries and find that on average if a nation had, by 1935 , depreciated its exchange rate to

${ }^{8}$ (cont'd) Public Works (whose spending fell from $\$ 25$ million to $\$ 13$ million between March 1931 and March 1933), the Department of the Interior (from $\$ 8$ million to $\$ 3$ million) and Subsidies to Provinces (from $\$ 17$ million to $\$ 13$ million).

- These effects are quite similar to those analyzed by Barro and Gordon (1983) in their study of the importance of reputation in monetary policy. 
$60 \%$ of its 1929 value, industrial production (in 1935) would have risen to $12 \%$ above its 1929 value. If the exchange rate had not depreciated over the period, industrial production in 1935 would be $16 \%$ lower than its 1929 value. These results suggest that Canada's failure to depreciate may explain the dramatic decline in her industrial production: an index of industrial production $(1929=100)$ was 67.2 in 1932 and 86.7 in $1935 . .^{10}$

The ex post evidence is of little use, however, in understanding the government's decision and its credibility. As the discussions in Section III show, the government, and indeed the opposition, thought that depreciation would have little or no impact on unemployment and only radical Western members of parliament argued that a depreciation/monetary expansion would reduce domestic unemployment levels.

(ii) Depreciation and the Government's Real Wealth

An alternative source of benefits to the government is the improvement in the government's balance sheet. Three types of benefits will be discussed: an increase in tax revenues, a reduction in the real value of outstanding debt, and a reduction in the real cost of servicing the debt. Examination of the government's

${ }_{10}$ This method cannot, however, give precise estimates of the output costs of exchange rate stability. The United States is omitted from the sample on the grounds that the Depression started there and that this, and the severity of the downturn, make her experience atypical. Canada's proximity to the United States may have made her experience more similar to that of the United States than to that of Europe. Secondly, and perhaps more importantly, the simple regressions of industrial production on depreciation are biased by the omission of the date of depreciation. Thus, for example, a depreciation by Belgium in 1935 is given the same weight as that of England in 1931. By 1935 Canada had depreciated her exchange rate by approximately $60 \%$, but this occurred in at least three steps (a $15 \%$ depreciation in late 1931, a further 15\% depreciation in early 1933 and a gradual $10 \%$ depreciation from then to 1935). It seems likely that different paths of depreciation between 1929 and 1935 would have led to different levels of industrial production in 1935. What can be learnt from the results of Eichengreen and Sachs is that in Europe there was a statistically significant and economically relevant negative correlation between the extent of depreciation and the level of industrial production. 
revenue and expenditure accounts - summarized in Table 1 - sheds light on the significance of these factors. In the year ending March 1929, interest on the public debt was $35 \%$ of government expenditures - a huge proportion. ${ }^{11}$ In the same year import taxes accounted for $40 \%$ of government revenue, while income and sales taxes accounted for $30 \%$.

The importance of import taxes for government revenue suggests that the government might be concerned that depreciation would reduce imports and thus import tax revenue. The government did not openly discuss this drawback to depreciation, however, they introduced extensive increases in tariff rates as imports fell reflecting a concern both with tariff revenue and employment in protected industries. Income tax rates were also raised to offset some of the early decline in tariff revenues.

The discussion of Section III shows that the size of the public debt was a key factor in the government's decision making with respect to the exchange rate, and the data in Table 1 provide some explanation for the concern. We assume that the government's policy decision is whether or not to engineer a depreciation through a monetary expansion. We use a simple accounting framework to look at the effect of such a policy on the government's debt load from two perspectives: firstly, we examine the effect of a monetary expansion/depreciation on the real value of outstanding debt; and secondly, we examine the more short run effects on the government's cash flow position, that is, the change in the value of interest payments and maturing debt in a particular year. ${ }^{12}$

11 For example, it is twice the level of 1947 (17.5\%) when World War II debt had been incurred, and twice the level of 1983 (18\%) when considerable concern was raised about the size of the government debt.

12 This appears to have been the calculation of immediate interest to the government. The Department of Finance, after September 1931, routinely prepared statements listing the principal and interest payments abroad that would come due in the following twelve months. See, for example, NAC M 1014 (R.B. Bennett Papers) p. 196679 - memo dated September 25, 1931. 
The potential benefit of a monetary expansion/depreciation to the government is the decrease in the real value of the stock of government debt. In order to measure the annual benefit of deciding to expand/depreciate in a particular year this stock benefit must be converted to a flow benefit, by multiplying by the interest rate. The real value of the government's funded debt $(D / P)$ is:

$$
D / P=(B d+e \cdot B f) / P
$$

where Bd represents bonds denominated in Canadian currency; Bf represents bonds denominated in foreign currency; $e$ is the price of foreign currency; and $P$ is the domestic price level. The government also issues fiat money $(H)$, so the benefit (R) to the government of an unanticipated monetary expansion is the reduction in the real value of its funded debt plus the real seignorage revenue:

$$
R=d H / P-d(D / P)
$$

Now, assume that the government expands the monetary base by $\mathrm{dH}$. In keeping with the historical context we examine a one-time monetary expansion, and initially assume that expectations of depreciation and inflation are not affected by this policy. Denote the percentage change in the high-powered money stock $\mathrm{dH} / \mathrm{H}=\pi$, and let this be accompanied by an increase in prices $\mathrm{dP} / \mathrm{P}=a \pi$ and depreciation of the exchange rate de $/ e=\beta \pi$. By parameterizing the effect of the monetary expansion on the price level and the exchange rate, the case of a neutral change in the money stock $(a=\beta=1)$ can be examined as a special case of the more general specification. Note that, if we let $a=\beta=1$, and assume dBd $=\mathrm{dBf}=0$, then by totally differentiating (1) and appropriate substitution, we find

$$
R=(B d / P) \cdot \pi+d H / P
$$

Thus the government benefits from a monetary expansion and the benefit rises (continuously) with the amount of expansion. 
The government's concern about the increase in the service cost of foreign currency denominated debt, reflects the fact that in the general case, where the assumption that $a=\beta=1$ is removed, the benefits of monetary expansion could be positive or negative:

$$
R=a \pi(B d / P)+(a-\beta) \pi(e \cdot B f) / P+\pi(H / P)
$$

If, as an extreme example, $a=0, \beta=1$, then,

$$
R=\pi[H-e \cdot B f] / P
$$

which is negative if $\mathrm{H}<\mathrm{e} \cdot \mathrm{Bf}$. While this example may be extreme, it is frequently assumed that $a<\beta$, that is, that prices adjust less rapidly than exchange rates (Dornbusch, 1976).

To capture the potential costs and benefits of monetary expansion to the Canadian government in the 1930 s we relax some of the simplifying assumptions. The domestic bond issues of the government $(\mathrm{Bd})$ are separated into gold bonds (Bdg) and Canadian currency bonds (Bdc). In theory, gold bonds should be combined with foreign currency denominated bonds. In practice, however, the government refused to pay gold to holders of such bonds if they were domiciled in Canada, so that only the gold bond holdings of foreign residents should be added to the foreign currency denominated bonds. ${ }^{13}$

13 See the correspondence of R.B. Viets, Solicitor to the Department of Finance. His standard response to requests for redemption in gold of bonds with a gold clause was

You say that you have a Dominion of Canada bond matured November 1 1934, which you desire to have paid in gold coin that is legal tender in Canada. Gold coin in Canada is worth only its face value in currency. The reason this is so is that gold coin cannot legally be melted down nor can it be exported. (National Archives of Canada [henceforth NAC], RG19, Vol. 3529, letter from Viets to Alphonse Jarry, 22 Nov. 1934.)

To help maintain the validity of this position the government attempted to prevent anyone from trading coins at a premium. Thus a Toronto firm advertising to buy gold coins at a $30 \%$ premium was sent an admonishing letter: "The result [of laws forbidding the export or melting down of gold coin] is that gold coin has no higher value than that of legal tender currency, and it must follow that to acquire the premium value of gold bullion the coin has to be melted down or exported". The firm was asked to "refrain in future" (NAC, RG19, Vol. 3529 \#10. letter from Viets to Arthur Brownstone, 14 February 1934). Elsewhere, W.C. Clark 
This framework can be used to quantify the effect of monetary expansion/depreciation on Canadian government wealth at a specific point in time - we choose two, September 1930 and April 1932. The first date corresponds to the government's refusal to expand the currency as requested by several members of the House of Commons during the special session of the House to discuss unemployment. The second date was chosen because in April 1932 the Inspector General of Banks forwarded to the Prime Minister a memo recommending that the government depreciate the exchange rate to parity with sterling (Bryce, 1986; 129). The author of the memo, Graham Towers, admitted that this could cause expectations of further inflation, but argued that "joining the sterling bloc would be regarded as an acceptable clearly defined goal".14

Table 2 presents a breakdown of the monetary issues and funded liabilities of the Canadian government on September 30, 1930 and March 30, 1932. On both dates nearly $80 \%$ of the debt is denominated in Canadian dollars, although in 1930 it is mostly gold bonds which by 1932 had been converted into Canadian currency debt. ${ }^{15}$

${ }^{13}$ (cont'd) (the Deputy Minister of Finance) advised Prime Minister Bennett that "There is of course the odd case where a person might buy gold coins on the speculative anticipation that when Canada revalues her gold such gold coins will be worth more than their present face value" but, he continued, such a market "is so small and of such a nature that it would not be recognized by a court" (NAC, RG19, Vol. 3979 G-1-10-3, letter dated 1 Mar. 1934). The government's position on payments outside Canada was clarified in a letter from Viets to the Canadian High Commissioner in London, Contracts payable in gold in Canada are sufficiently discharged by payments in legal tender currency, or at all events, damages for not paying in gold would be negligible. Of course a contract to pay gold in a country other than Canada would be governed by the laws of such country. (NAC, RG19, Vol. 3529 \#187, letter dated 23 July 1934.)

14 Bryce $(1986 ; 130)$, in his history of the Department of Finance, argues that the government's decision not to follow this recommendation reflected a 'debtor mentality', that is, concern about the country's credit rating.

is The conversion loan that effected this transformation (see below) occurred in late 1930, prior to the depreciation of the Canadian dollar and consequent rise in the Canadian price of gold in late 1931. 
Since so many desirable data are unavailable we can only find orders of magnitude of potential benefits and we do this by looking at three scenarios. In the first, we assume that prices and the exchange rate adjust proportionately with the monetary expansion $(a=\beta=1)$ and that all domestic gold bonds are to be honoured in gold. The second case differs only in that half the domestically issued gold bonds are expected to be honoured in Dominion notes and not gold. The $50 \%$ is a very rough guess as to the share of non-Canadian holdings of gold bonds, which the government continued to redeem in gold. Clearly if gold bonds were worth more in the United States than in Canada, there would be an incentive to export such bonds. ${ }^{16}$ We therefore believe the first scenario to be more relevant. (The second alternative is included to capture the possibility of incomplete markets.) Finally we drop the assumption that $a=\beta=1$, and assume that domestic prices do not increase while the exchange rate depreciates $(a=0$, $\beta=1$ ), reverting to the assumption that the gold clause in all bonds is honoured, and assuming that the price of gold rises with the price of foreign exchange.

For each case we examine the impact of a hypothetical once-and-for-all $15 \%$ increase in the stock of high powered money on the two dates. In March 1930 , 15\% was chosen because it is of the same order of magnitude as the depreciation by Canada's major trade competitors, Australia and Argentina. In October 1931, a further $15 \%$ depreciation would have meant that Canada had depreciated against the U.S. dollar and gold to roughly the same extent as sterling did.

${ }_{16}$ There is evidence that 'gold' coupons were sent by Canadians to the United States for redemption: The Attorney General of Ontario wrote to R.B. Bennett (who was Minister of Finance as well as Prime Minister) asking "Would there be any way that you could exert influence on the banks to stop this practice [Canadian individuals and institutions sending coupons to branches of Canadian banks in the United States where they must be redeemed in gold]? It is a very unpatriotic and unnecessary thing to do to-day" (NAC, M1013, P. 196817 - letter dated 14 Dec. 1931). 
The results are given in Table 3. The stock benefit measures the permanent increase in the government's real wealth, however, this must be converted into a flow benefit because the decision not to depreciate in September 1930, can be thought of as a decision to postpone depreciating for one year. Table 3 line lb, shows that monetary expansion/depreciation, under favourable assumptions, would have yielded less than $\$ 9$ million revenue in September 1930 - a relatively small contribution to the government's tax revenue of $\$ 296$ million. ${ }^{17}$ in March 1932 , the potential benefits are higher (and the possible loss is also lower) although it is still inconsiderable. The increase in the benefit is due to the conversion loan which redeemed a large portion of gold bonds and replaced them with non-gold bonds. If the gold clause in these bonds would not have been honoured, the 1930 potential benefits have been underestimated. The Monetary Times (10 January 1931) states that the new issue was mostly taken by Canadian residents.

We turn now to an analysis of the effect of monetary expansion and depreciation on the government's cash flow situation. The government was particularly concerned about the increase in the Canadian dollar value of its immediate commitments in sterling and the U.S. dollar. Table 4 indicates the extent of such obligations in the year following each of the two calls for expansionary policy: October 1930 - September 1931, and March 1932 - February 1933.

The conversion loan of May 1931 makes this counterfactual analysis rather difficult. This loan redeemed $\$ 638$ million of gold debt (originally issued to finance World War 1) with lower interest non-gold bonds. However, only \$52.9 million of that debt was to mature during the period October 1930 - September

17 The flow benefit is calculated using an interest rate of $4.5 \%$. Average yields on Dominion of Canada short term bonds in 1930-32 ranged from $4.43 \%$ to $5.08 \%$ (Nixon, 1937; 427). 
1931. In our analysis we have assumed that if the government had depreciated in September 1930, it would not have undertaken the conversion loan. Several points must be made here. In a world of sophisticated (rational?) agents, bond holders would have realized that such a conversion might influence the probability of depreciation, which would affect the price at which agents would have traded the gold bonds for non-gold bonds. The available historical evidence suggests, but in no way proves, that (a) after the reduction in its gold bond liabilities the government still saw depreciation as a costly strategy, and (b) the government would not have paid gold - or its market value in legal tender - to Canadian residents holding bonds. ${ }^{18}$

Line Illa in Table 4 shows that paying gold for bonds issued in London and New York after a depreciation would not have resulted in significant cost increases for the government, although if gold were paid to all Canadian gold bond holders the numbers are significantly larger. These costs would be offset by the seignorage revenue accruing from the monetary expansion ( $\$ 25$ million in 1930 or $\$ 23.6$ million in 1932). Thus if the government paid only $50 \%$ of its gold debts in gold (Table IV, line IIIb) it would make a net financial gain from the monetary expansion. It seems probable that as long as the government continued to pay gold on bonds issued externally, it would be able to borrow on the world capital market.

18 See fn. 13 above for evidence that the gold clause in bonds that were not converted was not honoured. This perhaps explains the lack of discussion, at the time of the conversion loan, of the omission of the gold clause in the new bonds. The records of the management committee set up to co-ordinate the conversion loan contain only one reference to the gold clause: the Comptroller of Loans was requested by $W$. Sellar (the Deputy Minister of Finance) to list the loans "giving in each case the exact wording of the clause, if any, appearing in the text of the bond in regard to the question of payment in gold" (NAC, RG19, Vol. 593, File 155-31, dated $20 \mathrm{Apr}$. 1931). There seems to have been no follow up to this memo. 
(iii) Depreciation and the Benefits of a Sound Reputation

The evidence of Section III suggests that the government's actions were constrained by the effects they would have on Canada's reputation for a 'sound' currency. The exact consequences and costs of a lost reputation were never described, although it seems clear that the government and opposition viewed the problem in black (no reputation) and white (good reputation) terms. As Barro and Gordon have pointed out, rational agents would include the expected costs due to a loss of reputation in determining the net benefits of a monetary policy. Such agents would then expect a policy change if it yielded net benefits.

The statement that Canada had a reputation for sound monetary policy, is implicitly a statement that holders of Canadian dollar denominated assets expected a zero rate of inflation, and loss of such a reputation is implicitly a statement that expected rates of inflation (and possibly their variance) would rise. This would impose the following costs on the government: (a) an increase in the interest rate that must be paid to Canadian holders of Canadian government bonds denominated in Canadian funds, to compensate for the higher expected inflation rate, and risk premium; (b) a similar premium would be needed for foreign holders of such bonds denominated in Canadian funds to compensate them for the exchange risk and expected depreciation; (c) since the fiat currency does not pay interest, the increase in expected inflation will reduce the desired holdings of real balances and therefore the flow of seignorage revenue.

The amount of the increased costs would depend on the shape of the demand curve for each liability. ${ }^{19}$ A plausible assumption is that issues of Canadian debt to foreigners faced an infinitely elastic demand curve; issues to

19 Calomaris $(1985 ; 15-16)$ raises this issue in the context of the Greenback period in the United States. 
Canadians faced a slightly downward sloping curve, and issues of high-powered money faced a more inelastic demand curve. Such a view would be consistent with the government's greater concern about losing its reputation in the international market (where all bond holders were paid in gold or the equivalent) than in the domestic market (where holders of high powered money were denied redemption in gold).

It might be argued that exchange risk would not have prevented Canadians from raising funds internationally, if they had borrowed in the lender's currency. This would transfer the exchange risk to the borrower, however, it might be assumed by a lender that a country willing to default by depreciating its currency, would be willing to default on principal if the former option were not open. Finally, we note that the government's statements could be interpreted as a fear that international credit would be unavailable at any price; that is, that markets were not of the perfect sort assumed in the last two paragraphs. ${ }^{20}$

The analysis of the impact of depreciation on the government's balance sheet could be repeated for the nation as a whole. Canada was a net debtor nation and the effect of depreciation on aggregate real wealth would come through the channels discussed above. Data are not available to undertake the kind of quantitative analysis that we have used to examine the effect on government wealth, however, the direction of effect would be the same.21

Thus, the government's failure to undertake an expansionary monetary policy resulted from two beliefs: that monetary expansion would increase the value of

20 For a discussion of credit rationing in markets with incomplete information see Stiglitz and Weiss (1981).

21 Data on stocks of bonds outstanding are unavailable, although there are data on the amount of interest paid outside Canada. In addition there are no data on whether the foreign held bonds were denominated in Canadian dollars, gold or foreign currency, or on net foreign holdings. 
external obligations without reducing the value of domestic obligations; and that, even if all contractual obligations were met, Canada would lose her reputation as a responsible debtor.

\section{Expectations and the Exchange Rate: an Empirical Test}

After early 1929 Canadian currency was de facto inconvertible, and the money stock was a policy variable under the control of the government. While in the long run the exchange rate, representing the relative purchasing power of one country's currency in terms of another, is determined by the behaviour of the supply of money relative to the demand for money in the two countries, in the short run the exchange rate, like other asset prices is strongly influenced by expectations. Thus expectations of future monetary policy would be important in determining to-day's exchange rate.

We have argued extensively above that the government made a clear commitment to maintain the gold basis of the Canadian dollar, which would prevent them from pursuing policies leading to inflation and depreciation. Since this appeared to be a rational policy the Canadian public viewed it as a credible commitment.

While the government's policy was unwavering, international factors also influenced the public's expectations about the level of the exchange rate. Specifically, the British abandonment of gold in September 1931 and the American suspension of gold convertibility in March 1933 both reduced the probability agents attached to Canadian maintenance of the gold basis. We assume that expectations went through three phases which were determined by these exogenous external events. Between January 1929 and September 1931, Canadians expected resumption at the traditional parity at any time. This view was 
encouraged by the government's insistence that the country was on a gold basis. While both politicians and economists ridiculed this assertion, there was continual discussion of the possibility and methods of returning to a de facto gold basis.22

The second phase began with the suspension of the gold standard in England. This clearly surprised the banking community. ${ }^{23}$ The President of the Canadian Bankers' Association wrote privately to a colleague on September 22, $1931::^{24}$

We have had two hectic days in Toronto. It was only Friday last that one of the big five banks [in England] assured its friends in Montreal that England had no idea of abandoning the gold standard. This information appeared in the press on Saturday, therefore the announcement which reached Toronto on Sunday evening came not only as a great surprise but aiso as a great shock.

It was now impossible to resume at the traditional parity with both sterling and the U.S. dollar (either $\mathrm{C} \$ 1=$ US\$1 or $\mathrm{C} \$ 4.86=£ 1$, but since $£ 1=$ US\$3.45 it was impossible for US\$4.86= $=\$ 4.86=£ 1$ ) and we argue that the uncertainty left Canadians in the position of having to hedge their bets.

Finally, after the middle of 1933, when the traditional relationship between the U.S dollar and sterling was reestablished, we assume that Canadians anticipated a similar return to parity. That is, a return to an exchange rate of C\$4.86 = US\$4.86 $=£ 1$, with all currencies depreciated by the same extent as measured in gold. The Bank of Commerce, in its Monthly Commercial Letter (June 1934 ; 5) reported that the return to normality was tantamount to the return to the gold standard. In December 1933 the President of the Bank of Toronto stated

22 See for example, Monetary Times, 3 May 1929, 17 Jan. 1930, 14 Feb. 1930. The Australian bankers had a similar reaction to the initial suspension of the gold standard there in early 1930: "Never for a moment did the banks consider the departure from parity to be anything more than a temporary expedient." (Schedvin, $1970 ; 156)$

23 See the article by Curtis in Monetary Times, 16 Oct. 1931.

24 From the Archives of the Bank of Nova Scotia; File A \#70-10 BNS Docs Section \#8. 
that

All present signs seem to point towards an ultimate international agreement upon a new gold standard for all countries, probably 40 to $50 \%$ below that now prevailing. The initiative will probably come from Washington or London or both acting jointly, and this country's problems in the Gold and currency field may find a solution at the same time.

These assumptions can be used to build a simple model of the Canadian exchange rate. Consider the case where each agent assigns a probability $\lambda$ to resumption at some future date $t_{1}$ at the traditional parity $\tilde{e}$ and a probability ( 1 - $\lambda$ ) to resumption at the rate $e^{*}, e^{*}>\tilde{e}$. If agents hold rational expectations then,

$$
t_{0} e^{e}=\lambda \tilde{e}+(1-\lambda) e^{*}
$$

where $t_{0} e_{t_{1}}^{e}$ is the expectation formed at $t_{0}$ for the exchange rate at $t_{1}$. If no new information becomes available in the period $\left(t_{0}, t_{1}\right)$ then equation (6) holds for $t_{0}<t<t_{1}$. If agents are risk neutral, then

$$
e_{t}={ }_{t} e_{t_{1}}^{e} \quad t_{0}<t<t_{1}
$$

At $t_{1}$ when the actual parity at resumption is revealed there will be an instantaneous jump in the exchange rate, however, the ex ante forecasting error is zero.

Combining equations (6) and (7), the model predicts that,

$$
e_{t}=\lambda \tilde{e}+(1-\lambda) e^{*}
$$

If $e_{t}$ is the Canadian dollar - U.S. dollar exchange rate (the price of a U.S. dollar in Canadian dollars) then our analysis of expectations implies that $\tilde{e}=1$, so that if $(\lambda)$, the probability of resumption at the old parity of U.S. $\$ 1=C \$ 1$, is unity then $e_{t}=\tilde{e}$. Similarly $e^{*}$ is equal to the inverse of the ratio of the current U.S. dollar price of sterling to 4.866 . This implies that if $\lambda=0$, then the price of sterling will be $C \$ 4.866$. 
The hypothesis that the level of the Canadian exchange rate was determined in the manner described in equation (16) can be indirectly tested by estimating the coefficients of the equation and testing whether or not they sum to unity. ${ }^{2 s}$ Using seasonally adjusted monthly data for the period October 1931 to December 1938 (using unadjusted data did not alter any of the results), and correcting for the observed first order autocorrelation, we estimated the equation. Interactive dummy variables were included to test for possible changes in the coefficients in March 1933 (when the U.S. restricted dealings in foreign exchange and gold) and February 1934 (after the U.S. Treasury purchase price for gold was fixed at $\$ 35.00 /$ ounce).

The estimating equation was

$$
e_{t}=a_{0}+a_{1} D 1+a_{2} D 2+a_{3} e_{t}^{*}+a_{4}\left(e_{t}^{*} \cdot D 1\right)+a_{5}\left(e_{t}^{*} \cdot D 2\right)
$$

where $e$ and $e^{*}$ are defined as above, and

$$
\begin{aligned}
D 1 & =1 \text { between March } 1933 \text { and January } 1934 \text { inclusive } \\
& =0 \text { otherwise } \\
\text { D2 } & =1 \text { between February } 1934 \text { and December } 1938 \text { inclusive } \\
& =0 \text { otherwise }
\end{aligned}
$$

The null hypothesis states that the following restrictions will hold:

$$
\begin{aligned}
& \text { (i) } a_{0}+a_{3}=1.0 \\
& \text { (ii) } a_{1}+a_{4}=0.0 \\
& \text { (iii) } a_{2}+a_{5}=0.0
\end{aligned}
$$

Estimation yields the following results:

2s This test determines whether or not the depreciation of the Canadian dollar against gold was a weighted average of the depreciation of the U.S. dollar and the pound sterling. Evidence that it is a weighted average of the two is consistent with our hypothesis of the determination of the Canadian exchange rate over the period. It is, of course, potentially consistent with alternative hypotheses, so it is worth emphasizing that the test would reject the hypothesis for most exchange rates - for example, the Australian dollar - over the period. 
$R^{2}=.97$ $(6.92)(1.38)$

$$
\begin{gathered}
0.36 \mathrm{D} 2 \\
(2.45)
\end{gathered}
$$

$+0.53 e^{*}-0.15\left(e^{*}\right.$

$(1.47)$
D1) $-0.38\left(e^{*} \cdot D 2\right)$
$(2.40)$

and the absolute values of the t-statistics are given in parentheses.

$$
\begin{array}{lll}
H_{0}: a_{0}+a_{3}=1.0 & t=0.72 & \text { df }=81 ; \text { accepted } \\
H_{0}: a_{1}+a_{4}=0.0 & t=-1.60 & \text { df }=81 ; \text { accepted } \\
H_{0}: a_{2}+a_{5}=0.0 & t=-0.84 & \text { df }=81 ; \text { accepted }
\end{array}
$$

The null hypothesis was accepted in each case, and the estimation suggests that there was a significant change in the coefficients in February 1934 but not in March 1933. The probability assigned to resumption at the par of U.S.\$1 = C\$1 is 0.49 before February 1934 and 0.85 after that date. Return to a parity of C\$4.866 $=£ 1$ was assigned a probability of about 0.53 before February 1934, and 0.15 after that date.

If the restrictions in fact held exactly, and there was no change in the coefficients in March 1933, better estimates of the coefficients could be obtained by imposing such restrictions, which yields the following results:

$$
\left.\hat{\mathrm{e}}_{\mathrm{t}}=\underset{(23.2)}{0.55}+\underset{(1.90)}{0.22 \mathrm{D} 2}+\underset{(18.59)}{0.44 e^{*}} \mathrm{t}-\underset{(1.90 f}{0.22\left(e^{*}\right.} \cdot \mathrm{D} 2\right)
$$

The probability estimates change only slightly $(\lambda=0.55$ before February 1934 and 0.77 after February 1934) suggesting that the results are quite robust. Interestingly there was considerable discussion in late 1933 of the possibility that the Canadian dollar would become more closely linked to sterling in an Empire currency block, (see discussions in the Wall Street Journal July and August 1933), but apparently these were outweighed by the stability suggested by the effect on expectations (of resumption at U.S.\$1 $=C \$ 1$ ) of the U.S. fixing of the price of gold. 
Contemporary reports provide some support for our hypothesis that speculation played an important role in determining the exchange rate. The Wall Street Journal (22 July 1930) reported that when the Canadian dollar had been at a slight discount in early 1930, some funds held by U.S. subsidiaries had not been repatriated as firms had anticipated the appreciation of the Canadian dollar. In a discussion in the Monetary Times (16 Oct. 1931) of the impact of the British depreciation in September 1931 on the value of the Canadian dollar, Curtis argues that the Canadian dollar depreciated because of the withdrawal of U.S. funds: "It may be costly, because of a possible depreciation in the Canadian dollar, to leave funds in Canada. And just because there was doubt in the minds of many as to Canada's monetary standard, there was a strong movement to transfer funds out of Canada".

There was little contemporary comment on the prognosis for the Canadian dollar, although there was frequent discussion in the Wall Street Journal and the Monetary Times of day-to-day fluctuations in the rate. For example, the Wall Street Journal (20 Jan. 1932) stated that, although in late 1931 "general nervousness had caused the rate to decline far below a level which foreign exchange authorities considered to be justified,... a recovery to anything like par is not looked for in best informed circles".26

The customary explanation of the level of the exchange rate in the early years following suspension is that the balance of payments happened to be in equilibrium at the traditional parity. First proposed by Knox in his 1939 study of monetary policy for the Rowell Sirois Royal Commision, this point of view was stated succinctly by Mclvor (1963):

That the Canadian dollar did not depreciate significantly in the early

36 No data on the future exchange rate are extant, although the Wall Street Journal occasionally refers to 15 - and 30-day futures. 
years of the depression was due to a net inflow of capital which reflected in part the confidence of foreign investors in the Canadian economy, in part Canadian government borrowing in New York and in part Canadian tariff policy which by curtailing imports lessened the demand for foreign exchange. There is no evidence, however, that these government measures which supported the dollar were adopted with that object in view. This result was rather of an incidental nature, but entirely in accord with the government's desire to maintain "sound" money. [emphasis added]

It seems rather unlikely (to us) that the Canadian balance of payments incidentally equilibrated at the traditional parity for nearly three years before October 1931 and for several years after 1934. Under a floating exchange rate the behaviour of the supply of money relative to the demand for money is central to the determination of the level of the exchange rate.

The explanation offered by Shearer and Clark (1984) is more intuitively attractive. They argue that during the first phase of the prohibition on exports of gold, the government needed, and obtained, the co-operation of the banks. They suggest that, particularly after mid-1931, the banks did not export gold on their own account, or for U.S. banks that were their customers, although it would have been profitable for them to do so. This, however, does not explain why the banks would co-operate with the government, nor does it explain the level of the exchange rate observed after October 1931, when the Canadian dollar depreciated about half as much as the pound, against the U.S. dollar.

VI. Conclusion.

Canada, in the period 1929-35 was an exception to the rule on the consequences of leaving the gold standard. Unlike many other countries, Canada did not experience reflation, and depreciation of her currency after she left the gold standard de facto in early 1929. The explanation we offer for Canada's atypical experience is that the principal authority responsible for determining the nation's money supply in the absence of a central bank - the Government of 
Canada - had strong reasons not to expand the money supply and hence depreciate the Canadian dollar.

The government opposed depreciation because it believed the costs of servicing its externally held debt (in terms of gold) outweighed the benefits of depreciating its domestically held debt and because it feared that departure from the rules of the gold standard would encourage a flight of capital. The public, on its part, treated the government's commitment to exchange rate stability as credible. Strong expectations of a return to the gold standard at the old parity dominated exchange rate expectations until Great Britain left gold in September 1931. Thereafter, until the U.S. re-established a new gold parity in March 1934, exchange rate expectations were determined by the probabilities the public attached to Canada following the policies of each of its major trading partners. 


\section{REFERENCES}

Beenstock, M., F. Capie, B. Griffiths (1984) "Economic Recovery in the United Kingdom in the 1930's", Bank of England Panel of Academic Consultants. Panei Paper \#23, April.

Bordo, M. and A. Redish (1987) "Why did the Bank of Canada emerge in 1935?" Journal of Economic History, XLVII, 405-18.

Brown, E. Cary (1956) "Fiscal Policy in the "Thirties: A Reappraisal" American Economic Review 46, 857-879.

Bryce, Robert B. (1986) Maturing in Hard Times (Montreal: McGill-Queen's University Press).

Calomaris, Charles W. (1985) "Understanding Greenback Inflation and Deflation: An Asset-Pricing Approach" unpublished ms. Northwestern University.

Choudhri, E. and L. Kochin (1980) "The Exchange Rate and the International Transmission of Business Disturbances: Some Evidence from the Great Depression" Journal of Money, Credit and Banking, XII, 565-74.

Clark, Carolyn and Ronald A. Shearer (1976) "New Evidence on Monetary Policy under the Finance Act, 1920 - 1934". Unpublished manuscript, University of British Columbia.

Dornbusch, R. (1976) "Expectations and Exchange Rate Dynamics", Journal of Political Economy, 84, 1161-76.

Eichengreen, B. (1985) "The Australian Recovery of the 1930's in International Comparative Perspective" Harvard University Discussion Paper, No. 1184. October.

Eichengreen, B. and J. Sachs (1986) "Exchange Rates and Economic Recovery in the 1930's" Journal of Economic History, XLV, 925-46.

Fisher, I. (1935) "Are Booms and Depressions Transmitted Internationally through Monetary Standards?" Bulletin of the International Statistical Institute, 28 (No. 1): 1-29.

Jonung, L. (1981) The Depression in Sweden and the United States: A Comparison of Causes and Policies' in K. Brunner, ed., The Great Depression Revisited (Boston: Martinus Nijhoff)

Knox, F.A. (1939) Dominion Monetary Policy, 1929-34 (Ottawa)

Mclvor, R.C. (1961) Canadian Monetary, Banking, and Fiscal Development (Toronto: Macmillan)

Nixon, S.E. (1937) "Interest Rates in Canada: the Course of Interest Rates, 1929-1937", Canadian Journal of Economics and Political Science 3, 421-434.

Rich, Georg (1987) "The Cross of Gold: Money and the Canadian Business Cycle 1867-1913" (unpublished manuscript). 
Schedvin, C.B. (1970) Australia and the Great Depression (Sydney: Sydney University Press).

Shearer, Ronald A, and Carolyn Clark (1984) 'Canada and the Interwar Cold Standard, 1920-35: Monetary Policy without a Central Bank' in Michael D. Bordo and Anna J. Schwartz, eds., $A$ Retrospective on the Classical Gold Standard (Chicago: University of Chicago Press)

Stiglitz, Joseph E. and Andrew Weiss (1981) "Credit Rationing in Markets with Imperfect Information" American Economic Review 71.

Watts, G.S. (1972) The Origins and Background of Central Banking in Canada', Bank of Canada Review 14-27. 
TABLE 1

\section{GOVERNMENT REVENUE AND EXPENDITURES}

$\begin{array}{lllll}1928 / 29 & 1929 / 30 & 1930 / 31 & 1931 / 32 & 1932 / 33\end{array}$

Expenditures

Interest

Ordinary

Special

124.989

121.566

236.213

121.289

268.269

17.831

121.151

254.252

55.959

134.999

5.998

13.570

407.389

431.362

223.529

356.950

371.349

455.420

Revenues

$$
\text { Import duties }
$$

Excise duties

Sales Tax

Income Tax

Other ordinary

Other special

$\begin{array}{rrrrr}187.206 & 179.429 & 131.208 & 104.132 & 70.072 \\ 63.684 & 65.035 & 57.746 & 48.654 & 37.833 \\ 83.007 & 63.409 & 34.734 & 59.606 & 82.191 \\ 59.422 & 69.020 & 71.048 & 61.254 & 62.066 \\ 62.144 & 64.518 & 54.851 & 56.063 & 54.474 \\ 5.476 & 4.540 & 6.622 & 7.028 & 4.492 \\ 460.940 & 445.952 & 356.210 & 336.737 & 311.128 \\ 103.990 & 74.601 & (51.179) & (94.625) & (144.291)\end{array}$

Source: Canada, Public Accounts, various years. 
TABLE 2

\section{FUNDED DEBT AND MONETARY ISSUES OF THE DOMINION GOVERNMENT*}

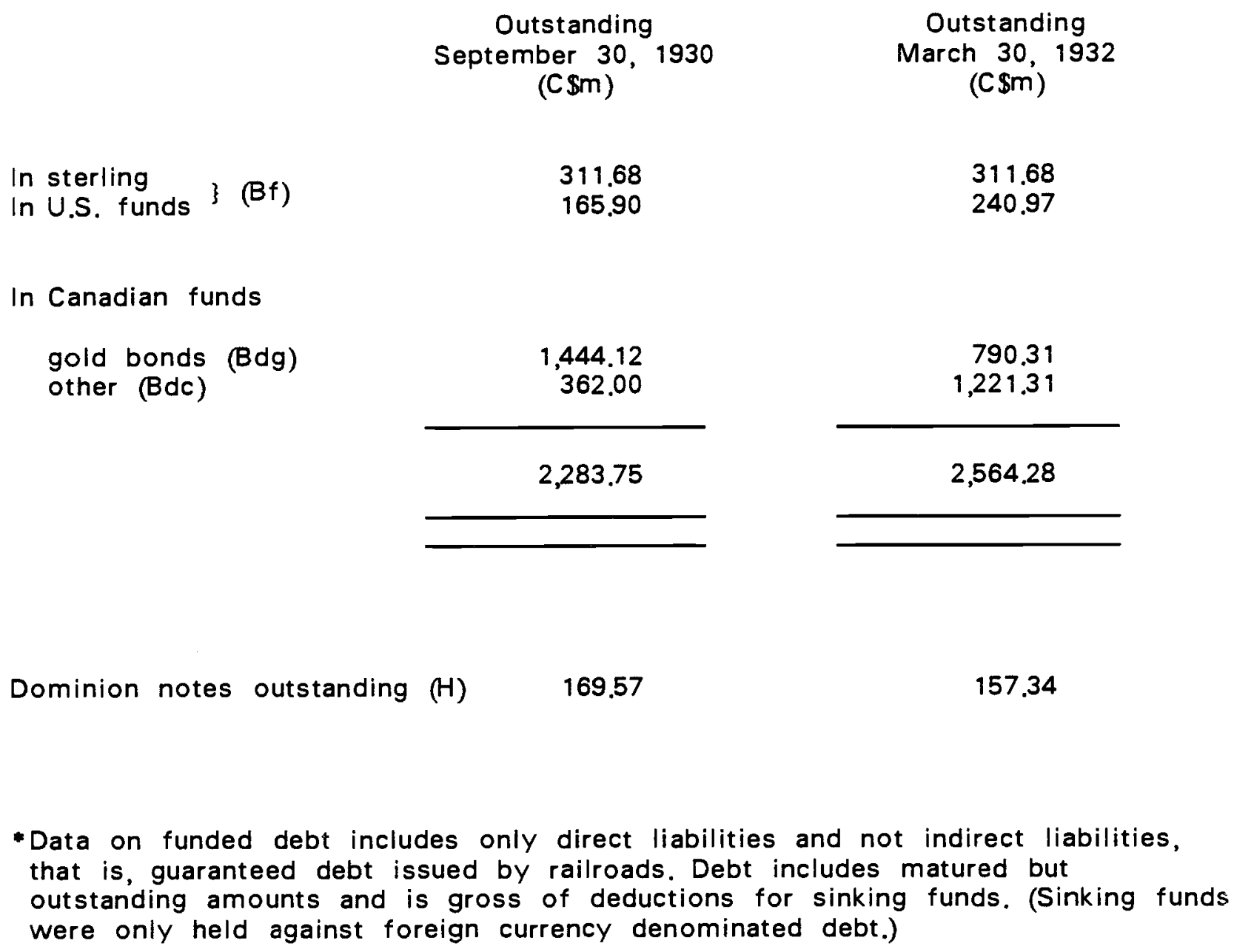

Source: Canada, Public Accounts, $1930 / 1$ and 1931/2.

Moody's Manual of Investments, Government Securities, 1930 and 1932 
TABLE 3

POTENTIAL BENEFITS FROM MONETARY EXPANSION

(1)

$$
\begin{aligned}
& a=\beta=1 \\
& B f+B d g
\end{aligned}
$$

is paid to

Benefits: Nominal

1 Sept, 1930: $\pi=d H / H=15 \%$

a) Stock benefit

b) Flow benefit

II March 1932: $\pi=\mathrm{dH} / \mathrm{H}=15 \%$

a) Stock benefit

b) Flow benefit

$\$ 79.74 \mathrm{~m}$

$\$ 3.59 \mathrm{~m}$

$\$ 206.80 \mathrm{~m}$

$\$ 9.31 \mathrm{~m}$

GNP

$\$ 5,728 \mathrm{~m}$

$\$ 4,699 \mathrm{~m}$
(2)

(3)

$$
(H+B d c) \pi \quad(H+B d c+(.5) B d g) \pi \quad\{H-e(B f+B d g)\} \pi
$$

$\$ 188.04 \mathrm{~m}$

$\$ 8.46 \mathrm{~m}$

$-\$ 262.82 m$

$-\$ 11.83 m$

$\$ 266.07 \mathrm{~m}$

$\$ 11.97 \mathrm{~m}$

$-\$ 177.84 m$

$-\$ 8.00 \mathrm{~m}$

Tax Revenue

$\$ 296 \mathrm{~m}$

$\$ 275 \mathrm{~m}$ 
TABLE 4

INTEREST AND MATURING DEBT OBLIGATIONS

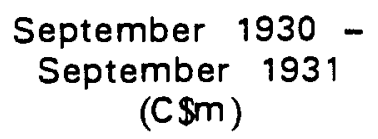

March 1932 -

March 1933

(C\$m) (C\$m)

1 Interest obligations

(a) London

(b) New York

11.14

10.09

11.14

79.90

11,96

(c) Canada - gold

16.71

36.67

(d) Canada - non-gold

1.67

61.49

(e) Canadian gold/New York

6.15

(f) Miscellaneous

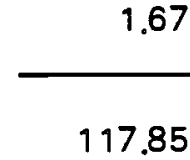

1.67

117.85

129.09

II Maturing debt

(a) Canada - gold

$52.93^{1}$

25.00

34.45

(b) New York

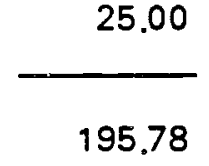

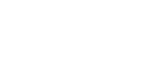

Sum $\mid$ and $\mid 1$

195.78

163.54

III Change in Canadian \$ costs: $15 \%$ depreciation
(a) No payment of gold on
6.93
3.46
Canadian gold debt ${ }^{2}$
(b) Payment of gold on $50 \%$ of
16.90
9.26
Canadian gold debt
(c) Payment of gold on all
26.80
15.05
Canadian gold debt
29.40
24.50

1. See text.

2. The debt payable in New York or Canada in line I(d) is counted as Canadian gold. 
Figure 1

WHOLESALE PRICE INDEX, CANADA AND USA, 1928=100 MONTHLY, SEASONALY ADJUSTED

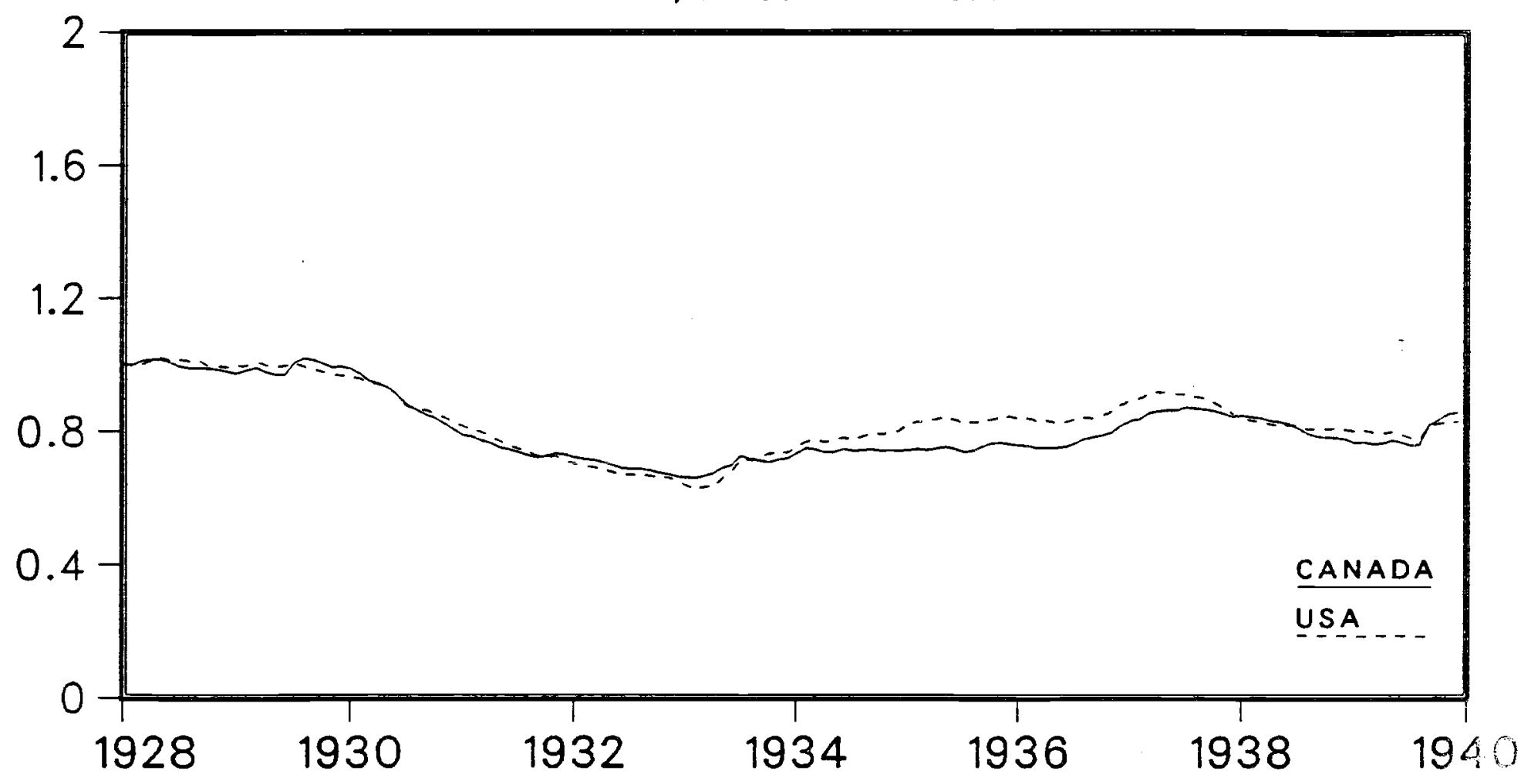

Figure 2

INDUSTRIAL PRODUCTION, CANADA AND USA, $1928=100$ MONTHLY, SEASONALY ADJUSTED

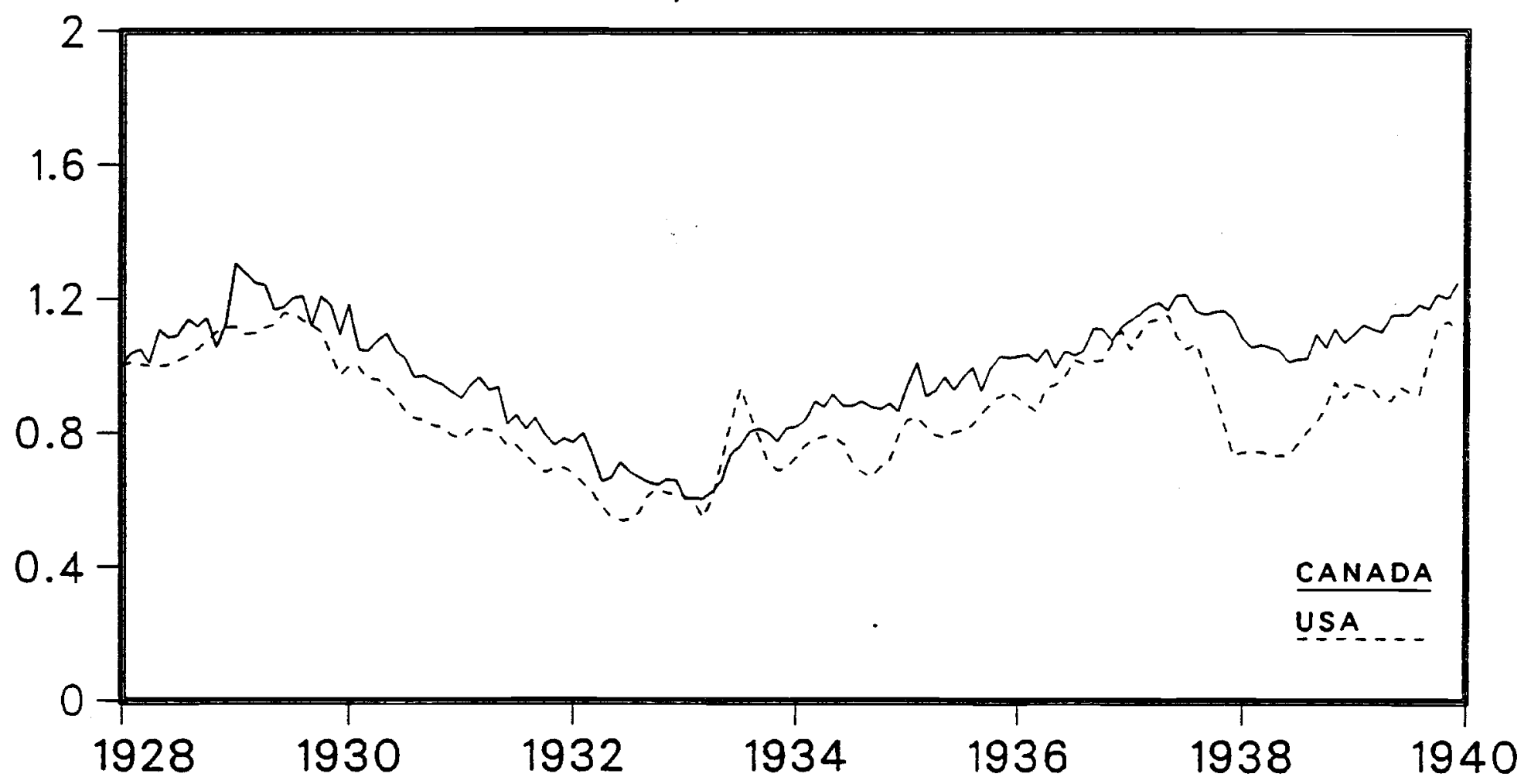


Figure 3

EXCHANGE RATES, CAN/USA, CAN/UK, 1928 $=100$ MONTHLY, SEASONALY ADJUSTED

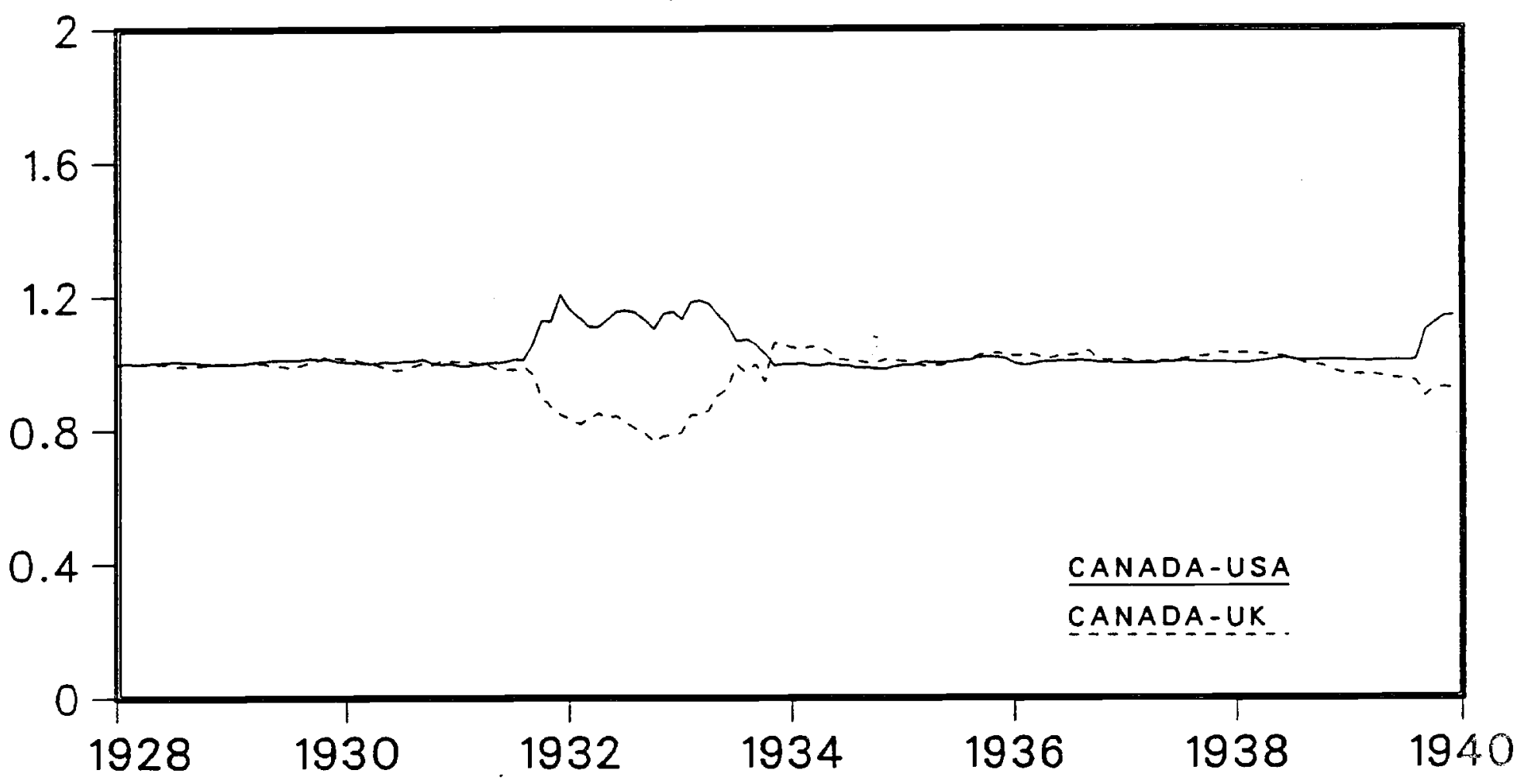

Figure 4

PRICE OF GOLD, 1928=100 MONTHLY

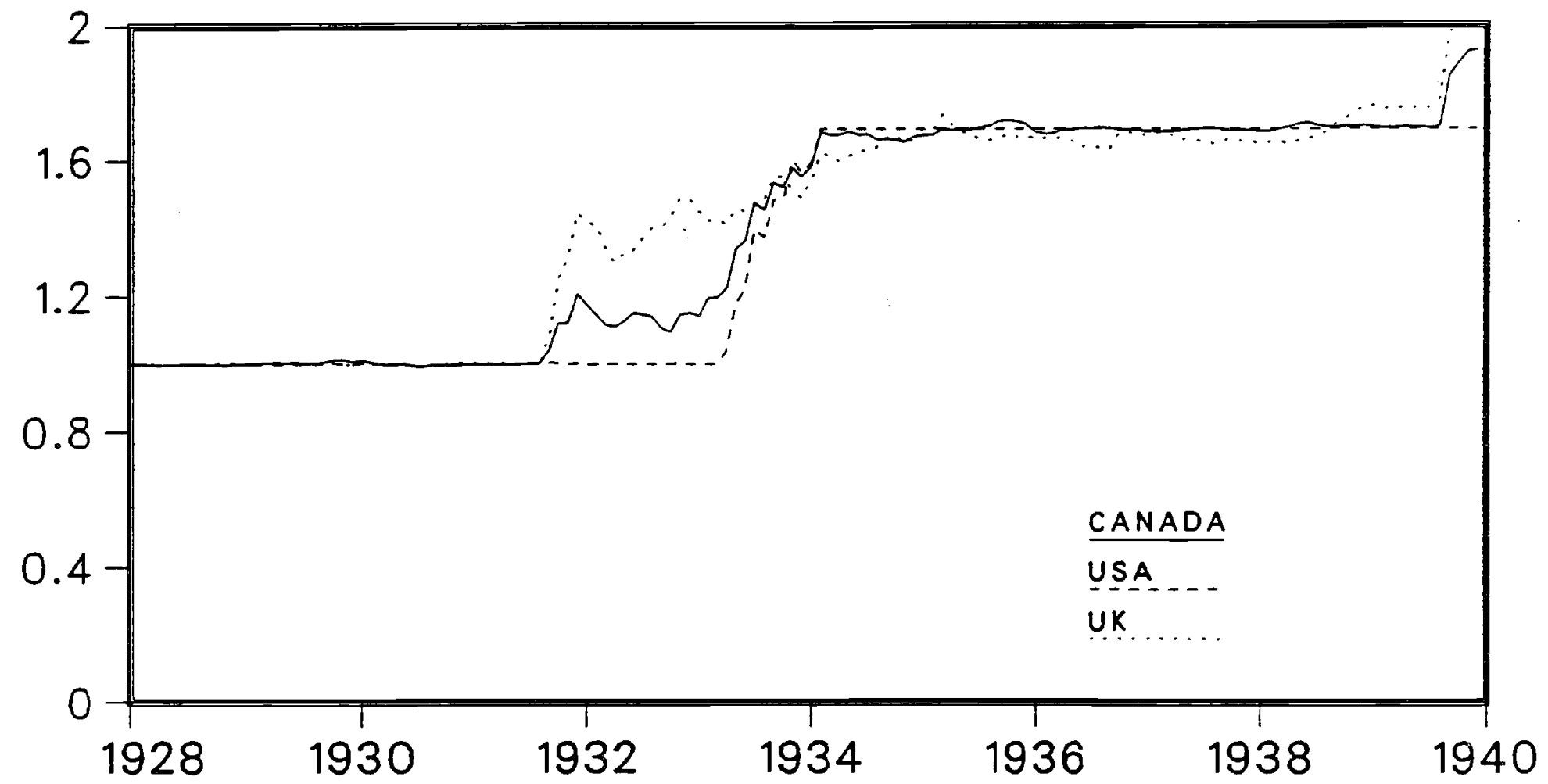


Figure 5

M1, CANADA AND USA, $1928=100$

MONTHLY, SEASONAUY ADJUSTED

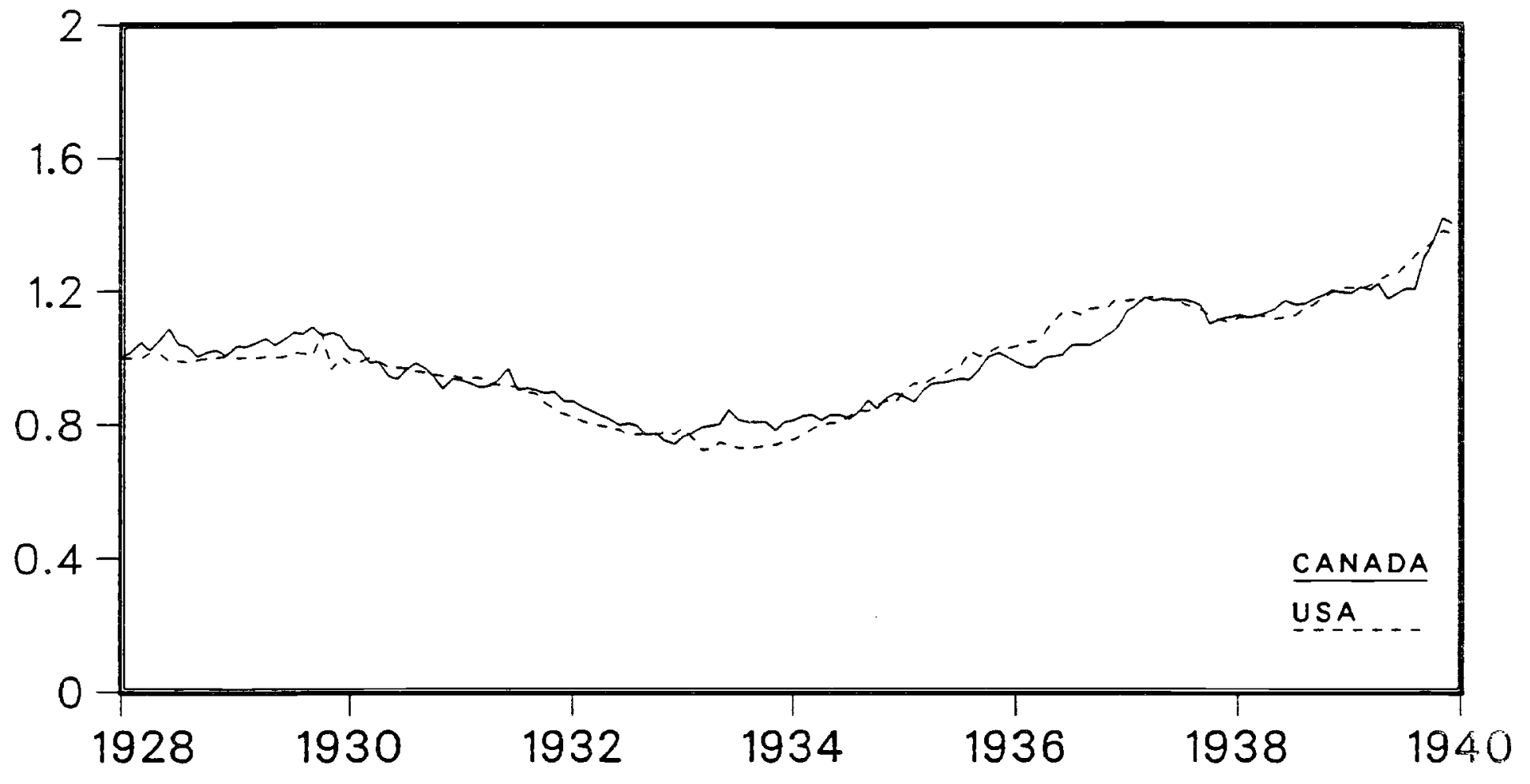

